\title{
THE EFFECT OF THE INFLUENCE OF PRODUCTS, PRICES, PROMOTIONS AND BRAND IMAGE ON SALES VOLUME IN CAHAYA MANDIRI TRADING BUSINESS
}

\author{
By \\ Hermanto ${ }^{1}$, Yudha Remofa ${ }^{2}$, Heriasman ${ }^{3}$ \\ ${ }^{1,2,3}$ Sekolah Tinggi Ilmu Ekonomi Indragiri (STIE-I) Rengat \\ Email: ${ }^{1}$ hermanto@stieindragiri.ac.id, ${ }^{2}$ yudharemofa@stieindragiri.ac.id, ${ }^{3}$ heriasman@stieindragiri.ac.id
}

\begin{tabular}{l}
\hline \hline Article Info \\
\hline Articlehistory: \\
Received:12-10-21 \\
Revised $: 19-11-21$ \\
Accepted: $26-11-2021$
\end{tabular}

Keywords:

Product, Price, Promotion,

Brand Image and Sales Volume

\begin{abstract}
The research was conducted at Cahaya Mandiri Trading Business, with the aim of seeing the effect of Product, Price, Promotion and Brand Image Effect on Sales Volume at Cahaya Mandiri Trading Business. The sample in this study were 87 consumers. The type of data used in this study is primary data in the form of quantitative data which is carried out by distributing questionnaires to consumers who shop. The analytical tool that the author uses is Multiple Linear Regression Analysis with a quantitative approach with the help of SPSS Software Version 21. The results of the study can be concluded that: (1) The product partially has a significant effect on Sales Volume at Cahaya Mandiri Trading Business. (2) Price partially has a significant effect on Sales Volume at Cahaya Mandiri Trading Business. (3) Promotion partially has a significant effect on Sales Volume at Cahaya Mandiri Trading Business. (4) Brand Image partially has a significant effect on Sales Volume at Cahaya Mandiri Trading Business. (5) Product, Price, Promotion and Brand Image simultaneously have a significant effect on Sales Volume at Cahaya Mandiri Trading Business.
\end{abstract}

Thisisan open accessarticleunderthe CC BY-SAlicense.

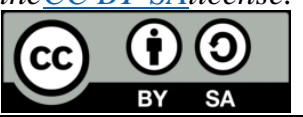

\section{CorrespondingAuthor:}

Hermanto

Dosen Sekolah Tinggi Ilmu Ekonomi Indragiri (STIE-I) Rengat, Indonesia

Email : hermanto@stieindragiri.ac.id

\section{INTRODUCTION}

The development of small and medium enterprises is increasing every year, especially in the Rengat district. An increase in the number of small and medium enterprises will certainly increase competition in the business that is run, especially the business that is run the same type as the old one. This is certainly a concern for business actors to run their business, as a business actor, of course, sales volume is the main thing.

Sales volume has a very important role in increasing the profit of a business. High sales volume will make it easier for business actors to make it easier to return the capital they have spent and pay obligations to the people they employ in their business. A business actor in every sale must be smart in making business plans and strategies in order to achieve the goals that have been set.

Based on the results of a pre-survey conducted at one of the independent Cahaya Trading Enterprises that sells products such as banana chips and onion cakes. The volume of sales that occurred in this business has decreased. The sales volume from the last three years has decreased. This is of course a special concern for the independent light trading business actors. Revenue from sales that occurred in 2017 amounted to Rp. 149,740,000. while in 2019 alone, trading business revenue was only Rp. 127,410,000. This is certainly a special concern for business actors in increasing their turnover. During the pre-survey, the researchers saw that the products they sell have competitors with other business actors. This is certainly one of the factors causing the decline in sales. In addition, the price offered is still inferior to similar competitors, competitors dare to provide prices below those sold by this independent light trading business. Promotions that are carried out are still traditional, not using social media which is currently popular. In addition, the brand image of the products sold by Cahaya Mandiri is not well known to consumers. 
From the background of the problem above, the researcher is interested in raising the title of this research, namely "The Influence of Products, Prices, Promotions and Brand Image on Sales Volume at Cahaya Mandiri Trading Business".

\section{RESEARCH METHOD}

This research was conducted at the Mandiri Cahaya Trading Business. The population in this study are consumers who shop at the Mandiri Cahaya Trading Business Object in the research of 665 people. Researchers only took samples using the accidental sampling method randomly using the Slovin formula. Then obtained a sample of 87 consumers. Data collection techniques used are interviews, observation and questionnaires.

Analysis of the data used using test instruments with validity and reliability tests, then using multiple linear regression, to find out how much influence between variables and using the $\mathrm{F}$ test and test to determine the effect simultaneously and partially and the last test using multiple correlation tests the coefficient of determination.

\section{RESULTS AND ANALYSIS}

The results of the validity and reliability tests of the independent and bound variants are shown below.

Tabel 1. Uji Validitas dan Reliabilitas

\begin{tabular}{|l|l|l|}
\hline Statement & $\begin{array}{l}\text { Uji Validitas } \\
\text { (Pearson Correlation 0,2108) }\end{array}$ & $\begin{array}{l}\text { Uji Reliabilitas } \\
\text { (Croanbach's Alpha 0,6) }\end{array}$ \\
\hline Product 1 & 0,714 & 0,792 \\
Product 2 & 0,713 & \\
Product 3 & 0,708 & \\
Product 4 & 0,725 & \\
Product 5 & 0,731 & 0,865 \\
\hline Price 1 & 0,781 & \\
Price 2 & 0,773 & \\
Price 3 & 0,819 & 0,881 \\
Price 4 & 0,922 & \\
Price 5 & 0,815 & \\
\hline Promotion 1 & 0,833 & \\
Promotion 2 & 0,914 & \\
Promotion 3 & 0,798 & \\
Promotion 4 & 0,852 & \\
\hline Brand Image 1 & 0,782 & \\
Brand Image 2 & 0,871 & \\
Brand Image 3 & 0,826 & \\
Brand Image 4 & 0,829 & \\
\hline Sales Volume 1 & 0,913 & \\
Sales Volume 2 & 0,952 & \\
Sales Volume 3 & 0,867 & \\
Sales Volume 4 & 0,859 & \\
Sales Volume 5 & 0,903 & \\
\hline
\end{tabular}

Sumber : Data Olahan

From all statement items, it can be seen that all statements of product, price, promotion, brand image and sales volume variables are valid and each product, price, promotion, brand image and sales volume variable is said to be reliable. To determine the effect of independent variables (product, price, promotion and brand image) on Sales Volume at Cahaya Mandiri Trading Business, hypothesis testing was carried out using several statistical analyzes. From the results of data processing, the regression coefficient is obtained and can be seen in the following table:

Table 2 : Koefisien Regresi

\begin{tabular}{|l|l|l|l|l|l|}
\hline \multirow{2}{*}{ Variabel } & \multicolumn{2}{|l|}{$\begin{array}{l}\text { Undstandardized. } \\
\text { Coefficients }\end{array}$} & $\begin{array}{l}\text { standardized } \\
\text { coefficients }\end{array}$ & \multirow{2}{*}{ T } & \multirow{2}{*}{ Sig. } \\
\cline { 2 - 4 } & $\mathrm{B}$ & Std. Error & Beta & & \\
\hline (Constant) & 1,915 &, 922 & & 2,076 &, 041 \\
\hline Product &, 665 &, 099 &, 733 & 6,692 &, 000 \\
\hline Price &, 379 &, 074 &, 385 & 5,151 &, 000 \\
\hline Promotion &, 386 &, 078 &, 390 & 5,367 &, 000 \\
\hline Brand Image &, 333 &, 061 &, 319 & 5,008 &, 000 \\
\hline
\end{tabular}


International Journal of Social Science (IJSS)

Vol.1 Issue.4 December 2021, pp: 513-516

ISSN: 2798-3463 (Printed) | 2798-4079 (Online)

DOI:https://doi.org/10.53625/ijss.v1i4.1037

Sumber : Data Olahan IBM SPSS Versi 21.0

From the results of the research above, it is obtained the multiple linear regression formula $\mathrm{Y}=1,915+0,665 \mathrm{X} 1+0,379 \mathrm{X} 2+0,386 \mathrm{X} 3+0,379 \mathrm{X} 4$. Which is where this research shows a positive relationship between each - each independent variable to the dependent variable. The partial test results show that the product has an effect on sales volume with sig $<0.05$, price has an effect on sales volume with sig $<0.05$, promotion has an effect on sales volume with sig $<0.05$ and brand image has an effect on sales volume with sig $<0.05$. To see the effect of product, price, promotion and brand image variables, see the table below:

Table 3 : Tabel ANOVA

\begin{tabular}{|ll|l|l|l|l|l|}
\hline \multicolumn{2}{|l|}{ Model } & $\begin{array}{l}\text { Sun Of } \\
\text { Squares }\end{array}$ & Df & $\begin{array}{l}\text { Mean } \\
\text { Square }\end{array}$ & F & Sig. \\
\hline $1 \quad \begin{array}{l}\text { Regression } \\
\text { Residual } \\
\text { Total }\end{array}$ & 165.662 & 2 & 41.416 & 59.817 & $.000^{\mathrm{b}}$ \\
& 56.775 & 82 & .692 & & \\
\hline
\end{tabular}

Sumber : Data Olahan IBM SPSS Versi 21.0

From the table above, it can be seen that sig $<0.05$, thus product, price, promotion and brand image simultaneously have a significant effect on sales volume. In addition, the level of relationship between all independent variables on the dependent variable in this study is in the criteria of a very strong relationship or very high influence and the contribution of the influence of the independent variable is $74.5 \%$, while the remaining $25.5 \%$ is influenced by other variables that are not investigated in this research. The results of the validity and reliability tests of the independent and bound variants are shown below.

Tabel 4. Uji Validitas dan Reliabilitas

\begin{tabular}{|l|l|l|}
\hline Statement & $\begin{array}{l}\text { Uji Validitas } \\
\text { (Pearson Correlation 0,2108) }\end{array}$ & $\begin{array}{l}\text { Uji Reliabilitas } \\
\text { (Croanbach's Alpha 0,6) }\end{array}$ \\
\hline Product 1 & 0,714 & 0,792 \\
Product 2 & 0,713 & \\
Product 3 & 0,708 & \\
Product 4 & 0,725 & \\
Product 5 & 0,731 & 0,865 \\
\hline Price 1 & 0,781 & \\
Price 2 & 0,773 & \\
Price 3 & 0,819 & \\
Price 4 & 0,922 & 0,881 \\
Price 5 & 0,815 & \\
\hline Promotion 1 & 0,833 & \\
Promotion 2 & 0,914 & 0,895 \\
Promotion 3 & 0,798 & \\
Promotion 4 & 0,852 & \\
\hline Brand Image 1 & 0,782 & \\
Brand Image 2 & 0,871 & \\
Brand Image 3 & 0,826 & \\
Brand Image 4 & 0,829 & \\
\hline Sales Volume 1 & 0,913 & \\
Sales Volume 2 & 0,952 & \\
Sales Volume 3 & 0,867 & \\
Sales Volume 4 & 0,859 & \\
Sales Volume 5 & 0,903 & \\
\hline
\end{tabular}

Sumber : Data Olahan

From all statement items, it can be seen that all statements of product, price, promotion, brand image and sales volume variables are valid and each product, price, promotion, brand image and sales volume variable is said to be reliable.

To determine the effect of independent variables (product, price, promotion and brand image) on Sales Volume at Cahaya Mandiri Trading Business, hypothesis testing was carried out using several statistical analyzes. From the results of data processing, the regression coefficient is obtained and can be seen in the following table: 
Table 5 : Koefisien Regresi

\begin{tabular}{|l|l|l|l|l|l|}
\hline \multirow{2}{*}{ Variabel } & \multicolumn{2}{|l|}{$\begin{array}{l}\text { Undstandardized. } \\
\text { Coefficients }\end{array}$} & $\begin{array}{l}\text { standardized } \\
\text { coefficients }\end{array}$ & \multirow{2}{*}{ T } & \multirow{2}{*}{ Sig. } \\
\cline { 2 - 4 } & $\mathrm{B}$ & Std. Error & Beta & & \\
\hline (Constant) & 1,915 &, 922 & & 2,076 &, 041 \\
\hline Product &, 665 &, 099 &, 733 & 6,692 &, 000 \\
\hline Price &, 379 &, 074 &, 385 & 5,151 &, 000 \\
\hline Promotion &, 386 &, 078 &, 390 & 5,367 &, 000 \\
\hline Brand Image &, 333 &, 061 &, 319 & 5,008 &, 000 \\
\hline
\end{tabular}

Sumber : Data Olahan IBM SPSS Versi 21.0

From the results of the research above, it is obtained the multiple linear regression formula $\mathrm{Y}=1,915+0,665 \mathrm{X} 1+0,379 \mathrm{X} 2+0,386 \mathrm{X} 3+0,379 \mathrm{X} 4$. Which is where this research shows a positive relationship between each - each independent variable to the dependent variable. The partial test results show that the product has an effect on sales volume with sig $<0.05$, price has an effect on sales volume with sig $<0.05$, promotion has an effect on sales volume with sig $<0.05$ and brand image has an effect on sales volume with sig $<0.05$. To see the effect of product, price, promotion and brand image variables, see the table below:

Table 6 :Tabel ANOVA

\begin{tabular}{|ll|l|l|l|l|l|}
\hline \multicolumn{2}{|l|}{ Model } & $\begin{array}{l}\text { Sun Of } \\
\text { Squares }\end{array}$ & Df & $\begin{array}{l}\text { Mean } \\
\text { Square }\end{array}$ & F & Sig. \\
\hline $1 \quad$ Regression & 165.662 & 2 & 41.416 & 59.817 & $.000^{\mathrm{b}}$ \\
& $\begin{array}{l}\text { Residual } \\
\text { Total }\end{array}$ & $\begin{array}{l}56.775 \\
222.437\end{array}$ & 82 & .692 & & \\
\hline
\end{tabular}

Sumber : Data Olahan IBM SPSS Versi 21.0

From the table above, it can be seen that sig $<0.05$, thus product, price, promotion and brand image simultaneously have a significant effect on sales volume. In addition, the level of relationship between all independent variables on the dependent variable in this study is in the criteria of a very strong relationship or very high influence and the contribution of the influence of the independent variable is $74.5 \%$, while the remaining $25.5 \%$ is influenced by other variables that are not investigated in this research.

\section{CONCLUSION}

Based on research conducted by researchers, the product partially has a significant effect on sales volume, price partially has a significant effect on sales volume, promotion partially has a significant effect on sales volume and brand image partially has a significant effect on sales volume. Taken together these two variables product, price, promotion and brand image have an effect on sales volume. Product has a more dominant influence on sales volume when compared to price, promotion and brand image in the research conducted.

\section{REFERENCES}

[1] Hermanto, H. Pengaruh Persaingan Dan Harga Terhadap Keputusan Pembelian Sepeda Motor Pada Cv. Greentech Belilas Kabupaten Indragiri Hulu. Jmbi 2018, 7, 54-63.

[2] Hermanto, H.; Corrina, F.; Supriyadi, A. Faktor - Faktor Yang Mempengaruhi Keputusan Pembelian Dan Dampaknya Pada Kelangsungan Usaha Mikro Kecil Menengah Pada Usaha Fotocopy Sekecamatan Rengat. Jmbi 2019, 8, 328-341.

[3] Hermanto, H. Pengaruh Produk Dan Kepuasan Konsumen Terhadap Keputusan Pembelian Pada Pt. Alfa Scorpii Pematang Reba. Jmbi 2018, 7, 106-113.

[4] Apriansyah, R. Pengaruh Kualitas Pelayanan Dan Promosi Terhadap Volume Penjualan Pada Pt. Prioritas Rengat. Jmbi 2018, 7, 37-45.

[5] Kotler, Philip and Kevin Lane Keller, 2011. Manajemen Pemasaran, Edisi 13 Jilid 1 dan 2, Alih Bahasa : Bob Sabran, Erlangga, Jakarta.

[6] Mowen, J.C. and Minor, M. 2002, Perilaku Konsumen. Alih bahasa: Dwi Kartini Yahya, Erlangga, Jakarta.

[7] Dharmaresta, Basu Swastha dan Ibnu Sukotjo, 2013, Pengantar Bisnis Modern, Edisi Ketiga, Liberty, Yogyakarta.

[8] Lovelock, Christopher., Jochen Wirtz, Jacky Mussry, 2014, Pemasaran Jasa, Edisi 7, Jilid 2, Erlangga, Jakarta. 